\title{
Experimentální ověření teorie spirály mlčení v online a offline prostředíl
}

\section{Experimental Test of the Spiral of Silence Theory in Online and Offline Environments}

\author{
František Kalvas, Lucie Přibylová
}

\begin{abstract}
The article reports the results of a test of the Spiral of Silence Theory that was introduced by Elizabeth Noelle-Neumann. The real process of the spiral of silence assumes that people (in the putative position of a minority) do not express their opinion or join the opinion of the majority because they have a fear of isolation. Tamás Bodor has argued that the theory does not function in all tests when (1) the process is timelimited, meaning that we can observe a public debate of an actual problem only for a short time and with the condition that the public forms two opposing opinion camps and (2) the key dependent variable is measured in an inappropriate way (e.g. researchers interview participants using a questionnaire on the hypothetical willingness to speak out). The solutions used with our test were: (1) we used four controversial themes, resulting in a greater probability of finding the functional process of the increased silence of the minority, and (2) we measured the key dependent variable as speaking behaviour during the laboratory experiment. Two laboratory experiments were part of this research; the first contained 42 and the second contained 43 students from the University of West Bohemia in Pilsen. The experiments had the same design: (1) measuring of attitudes through a questionnaire (phase 1); (2) discussion on an internet blog (an anonymous online environment); and (3) discussion in a focus group (an offline environment). The first half of the respondents discussed anonymously online (phase 2) and thereafter offline (phase 4), and the other half participated in the experiment in the reverse order of environments. We measured attitudes again in phase 3 and at the end of the experiment (phase 5). The article investigates whether participants with minority attitudes are more frequently silent and how this relationship is moderated by fear of isolation and by the communication environment. Our results prove that the probability a participant will speak her opinion rises in an anonymous online environment. The results support the Spiral of Silence Theory - participants expressing minority attitudes are more frequently silent, but only when they express higher fear of isolation. Participants expressing lower fear of isolation are not influenced by minority or majority attitudes regarding the speaking of their opinion. Finally, the main contribution of our paper is the experimental replication of results obtained through hypothetical measures.
\end{abstract}

KEY WORDS experiment, Spiral of Silence Theory, anonymous online environment, offline environment

Sociální studia / Social Studies 2/2017. S. 27-47. ISSN 1214-813X.

Tento článek vznikl za finanční podpory grantového projektu ZČU SGS-2014-071 „Spirála mlčení v online a offline prostředi““. Rádi bychom také poděkovali Šárce Syslové, výkonné redaktorce Sociálních studií, za dlouhodobou trpělivou komunikaci s naším týmem. Poděkování také patří celkem čtyřem anonymním recenzentům této a o několik let starší verze naší studie - jejich kritické poznámky nám významně pomohly zacílit text, zlepšit teoretickou část práce a projasnit závěr. V neposlední řadě děkujeme našim participantům - bez jejich účasti by nebylo co zkoumat. 


\section{Teorie spirály mlčení}

Na fenomén teorie spirály mlčení jako první poukázala Elizabeth Noelle-Neumannová ve svém článku „The Spiral of Silence: A Theory of Public Opinion“ (1974), v němž popsala proces formování veřejného mínění. Podle autorky se veřejné mínění tvoří v rámci interakcí jednotlivců s jejich sociálním okolím a klíčovou součástí tohoto procesu je strach jedinců, že budou kvůli svému mínění izolováni či vyloučeni svým okolím. Noelle-Neumannová prakticky zkoumala ochotu participanta vyjádřit mínění k danému tématu v hypotetické situaci: dlouhé cestě ve vlaku se zastánci opačných postojů než má respondent. Teorii spirály mlčení autorka vysvětlila v několika základních bodech:

(1) Lidé si neustále tvoří obraz o rozložení mínění ve svém okolí. Intenzita pozorování prostředí je závislá na rozsahu zájmu o téma, ale i na pravděpodobnosti, že by se musela osoba k tématu veřejně vyjádřit.

(2) Jedinec je ochotnější vyjádřit své postoje, pokud věří, že jsou dominantní ve veřejném mínění nebo jsou tyto postoje veřejně prezentované.

(3) Distribuce postojů a příslušných mínění se může lišit. Je to proto, že mínění, jehož distribuce je přeceňovaná, je veřejně prezentováno častěji, než odpovídá rozložení př́islušného postoje ve veřejnosti.

(4) Existuje pozitivní vztah mezi hodnocením současné distribuce mínění a budoucím vývojem této distribuce. Pokud bude osoba o určitém mínění soudit, že je momentálně dominantní, bude si ta samá osoba ve stejnou chvíli velmi pravděpodobně myslet, že bude dominantní i v budoucnu. Síla korelace těchto dvou hodnocení (současné a budoucí distribuce) není shodná v př́ípadě všech mínění - slabá korelace je indikátorem toho, že veřejné mínění momentálně prochází procesem změny.

(5) Pokud se hodnocení budoucího a přítomného rozložení mínění liší, pak je to předpoklad budoucího rozložení, který určuje momentální individuální ochotu vyjádřit své mínění $\mathrm{k}$ tématu.

V následujícím článku Noelle-Neumannové „,Turbulences in the Climate of Opinion“ (1977) byl vysloven další důležitý předpoklad. Lidé pocit’ují strach z izolace, který je základním hybatelem procesu spirály mlčení - motivuje jedince ke sledování rozložení mínění. Podle Noelle-Neumannové strach z izolace také vede jedince, kteří se domnívají, že jsou v menšině k tomu, aby raději o svém postoji mlčeli. Podle ní je tento strach vlastní všem lidem, byt' jej různí jedinci pocit’ují v různé míře. Pokud by lidé strach z izolace nepocit'ovali, proces spirály mlčení by nefungoval dle předpokladů této teorie (Noelle-Neumannová 1977, 1993).

Noelle-Neumannová však empiricky netestovala, zda strach z izolace motivuje ke sledování názorů druhých a zda je prríčinou tendence $\mathrm{k}$ mlčení - takové působení strachu z izolace doložily až pozdější studie. Noelle-Neumannová pouze na experimentech s konformitou Solomona Asche (1956) ukázala, že strach z izolace existuje a že tlak na konformitu přiměje některé jedince odpovídat v rozporu s jejich přesvědčením. Pokud pak ve svých datech našla evidenci, že někteří respondenti v hypotetické otázce přiznali tendenci raději o svém menšinovém názoru mlčet, pouze teoreticky předpokládala, že příčinou byl strach z izolace. Působení strachu z izolace jako příčiny spirály mlčení potvrzují až současné studie. Andrew F. Hayes a kol. (2011) ukazují, že zvýšený strach z izolace souvisí se zvýšeným zájmem o průzkumy veřejného mínění. Jörg Matthes a kol. (2012) dokládají, že osoby s vyšší hladinou strachu 
z izolace jsou náchylnější k sebe-cenzuře, pokud čelí názorové většině. Kurt Neuwirth a kol. (2007) a Sei-Hil Kim (2012) testovali alternativní vysvětlení př́čin mlčení, která zpochybňují nutnost působení strachu z izolace. Ve svých studiích pak dokládají, že efekt strachu z izolace přetrvá i při kontrole váhy vlastního názoru (efficacy), vnímané kontroly nad situací (perceived behavioural control), subjektivních norem, sledování médií, pevnosti vlastního názoru, vnímané síly opačného názoru, znalosti problému a zájmu o něj a vnímané shody s referenční skupinou a názorovou většinou.

Neuwirth a kol. (2007) a Kim (2012) také mnohem podrobněji než Noelle-Neumannová rozebírají podstatu konceptu strachu z izolace. Obě studie v rozboru vycházejí z teorie komunikační ostýchavosti (communication apprehension) a rozlišují strach z izolace (1) jako osobnostní rys, (2) jako přechodný stav a (3) Neuwirth ještě samostatně vyčleňuje strach spojený konkrétním tématem. Strach z izolace jako osobnostní rys se uplatňuje ve všech situacích, kterými osoba prochází. V tomto rysu se sice jednotliví lidé liší - rozhodně nejde o konstantu, všichni nevykazují shodnou hladinu strachu, ale u jednoho jedince se hladina tohoto strachu v čase př́liš nemění. Strach z izolace jako přechodný stav vyvolává nějaká situace, ve které má osoba projevit svůj konkrétní názor. Tento strach se zánikem situace postupně odezní. Neuwirth strach spojený s konkrétním tématem označuje jako „vlastní strach z izolace“, jedinečný typ strachu, který teorie komunikační ostýchavosti nepopisuje - nachází se někde mezi trvalým rysem a konkrétní situací. Neuwirth to vysvětluje tím, že teorie komunikační ostýchavosti se zabývá „interpersonální komunikací, nikoli veřejným diskurzem“ (Neuwirth a kol. 2007: 453). Již nyní avizujeme, že $\mathrm{v}$ naší studii budeme dále studovat strach z izolace pouze jako osobnostní rys, stejně postupovali i Hayes a kol. (2011), Kim (2012) a Matthes a kol. (2012).

Teorie spirály mlčení byla prokazována mnoha různými způsoby. Nejkomplexnější srovnání analýz nalezneme v článku Carolyn Glynnové a kol. (1997). Autoři shromáždili studie publikované mezi lety 1973-1994, které zkoumaly vztah mezi vnímanou podporou postojů a ochotou vyjádřit se. Většina vybraných studií dospěla ke kladnému výsledku v korelaci vnímané podpory a ochoty vyjádřit se. Podle Thomase Petersena (2012) je velmi těžké potvrdit fungování teorie spirály mlčení. Tento fakt ale nesnižuje zajímavost teorie a mnoho autorů se ji stále snaží testovat. Mezi autory, již se teorií zabývali, patř́i také Matthes a kol. (2010), kteří zkoumali vliv pevnosti postoje na vyjádření se, ale také Kim (2012), jenž studoval klasický vztah mezi vnímanou podporou vlastního postoje a ochotou vyjádřit se v různých hypotetických situacích. Tento vztah ověřoval mimo jiné i Neuwirth (2000). Pomocí telefonních interview se jeho tazatelé snažili zjistit míru vyjádření se v hypotetické situaci (večírek) o politických kandidátech na prezidenta. Dietram Scheufele a Patricia Moyová (2000) upozornili na kulturní rozměr. Podle autorů jsou mezikulturní rozdíly hlavním důvodem rozdílné ochoty vyjádřit svůj postoj, protože lidé se odlišně chovají v různých sociálních a kulturních podmínkách. Matthes a kol. (2012) ve své mezikulturní studii předpokládali platnost vztahu: vyšší strach z izolace vede k vyšší ochotě $k$ sebe-cenzuře (nevyjádření se). S výjimkou Číny se jim tyto výsledky potvrdily ve všech zkoumaných zemích.

Podle Tamáse Bodora (2012) má spirála mlčení slabé empirické postavení vinou dvou faktorů: (1) nevhodné načasování testu a (2) nedostatečná operacionalizace klíčové závisle proměnné. První bod znamená, že kontroverzní témata podporují proces spirály mlčení pouze 
v určité fázi proměňování veřejného mínění. Navíc musí také dojít ke zjevnému posunu rozvrstvení mínění a utvoření dvou soupeřících táborů. Výzkum Bodora ukazuje, že preference kandidáta při prezidentských volbách se stala významným ukazatelem ochoty otevřeně veřejně vyjádřit postoj pouze ve druhém ze tří zkoumaných týdnů volební kampaně. Z toho usuzuje, že první a třetí týden proces spirály mlčení ještě nebo již neprobíhal. V druhém bodě Bodor argumentuje, že doposud probíhalo nedostatečné měření ochoty vyjádřit se. Tato ochota byla měřena otázkou: Jak moc byste byl/a ochoten/a vyjádřit své postoje v hypotetické situaci? (Př́́klady měření hypotetických situací: Kim (2012) - (1) TV interview, (2) online fórum, (3) konverzace s přáteli; Matthes a kol. (2012) - (1) konverzace s přáteli, rodinou a kolegy, (2) diskuze na veřejnosti, (3) participace na demonstraci, (4) podpis petice; Francis Dalisay a kol. (2012) - (1) setkání v rámci komunity, (2) TV interview, (3) barbecue, (4) restaurace). Bodor se proto participantů ptá na to, během kolika pracovních dní v posledním týdnu na pracovišti diskutovali o politických tématech.

Naše studie navazuje na argumenty Bodora (2012) a snaží se řešit jeho námitky vůči dosavadním empirickým testům následovně: (1) používá čtyři kontroverzní témata pro snížení rizika, že některé téma nebude správně načasované, tedy nebude podporovat tvorbu spirály mlčení, (2) výzkumný design je laboratorní experiment, který sleduje respondentovo komunikační chování, místo abychom se pouze hypoteticky ptali respondentů na ochotu vyjádřit se.

Dosavadní zkoumání spirály mlčení bylo zaměřené většinou na její ověřování v konverzaci tváří v tvář (offline). Naše studie ověřuje teorii ve dvou kontextech, nejenom v diskuzi tváŕí v tvář jako u předchozích autorů, ale také v internetové komunikaci. Anne Schulz a Patrick Roessler (2012) ve svém článku popisují rozdíly ve formování veřejného mínění $\mathrm{v}$ prostředí internetově zprostředkované komunikace a v komunikaci tváří v tvář. Názory, které jedinec vyjádří $\mathrm{v}$ internetové diskuzi, nemusí nutně vyslovit také $\mathrm{v}$ běžné komunikaci tváří v tvář, obzvláště pokud se v televizním vysílání objevuje častěji nepřátelské stanovisko. Podle autorů prozatím nedochází k nahrazování diskuze tváří v tvář internetovou komunikací, protože internet využívají stále nejvíce mladí lidé a existuje velké množství lidí, kteří přístup $\mathrm{k}$ internetu nemají (staří lidé, chudí lidé). O digitální propasti hovoří také např. Jan Van Dijk (2005).

Podle Shirley Ho a Douglase McLeoda (2008) existuje zásadní rozdíl mezi vyjadřováním se v offline a anonymním online prostředí. Míra ochoty vyjádřit se je závislá na charakteristikách, které tyto dva kontexty mají. Komunikace tváří v tvář je typická mluveným slovem a lze díky ní také pozorovat množství neverbálních signálů a též status jednotlivce. Internetově zprostředkovaná debata má obvykle formu textu a vyznačuje se anonymitou. Tato anonymita činí status hưře pozorovatelným. Z toho vyplývá, že lidé, kteří nejsou kvůli nižšímu statusu ochotni mluvit o nějakém tématu v konverzaci tváří v tvár̆, mohou být ochotnější komentovat toto téma na internetu. Výsledky jejich studie ukázaly, že lidé jsou méně ochotní témata diskutovat tváŕí v tvář než na internetu a rozdíl v této ochotě se ještě zvýší přímo úměrně jejich strachu $\mathrm{z}$ izolace.

Podobně i Michael McDevitt a kolektiv (2003) docházejí k závěru, že by lidé měli být ochotnější diskutovat kontroverzní témata na internetu než tváří v tvář, ale nabízejí odlišné zdůvodnění. Nejprve rekapitulují tři důležité podmínky pro fungování spirály mlčení - 
jedinci (1) musí být motivovaní k prozkoumávání názorového klimatu, (2) musí být schopni přesně odhadnout názorové klima a (3) musí věřit, že názorová většina může nějak trestat jedince za odlišné názory. Na základě teoretického rozboru a shrnutí dosavadních poznatků pak autoři tvrdí, že všechny tři podmínky jsou v prostředí počítačem zprostředkované komunikace oslabené, a tudíž lze očekávat, že i proces spirály mlčení bude $\mathrm{v}$ tomto prostředí oslaben. Navíc, sami prímo experimentálně ověřili, že pokud jedinec prezentoval svůj postoj v online prostředí, jevil se prezentovaný názor účastníkům diskuse méně extrémní, než kdyby byl prezentovaný $\mathrm{v}$ diskusi tváŕí $\mathrm{v}$ tvár. $\mathrm{Z}$ tohoto výsledku můžeme vyvodit oslabení procesu spirály mlčení - v prostředí internetu se menšina nebude tolik obávat projevovat své názory, protože se názory většiny nebudou jevit tak vyhrocené.

\section{Experimentální design při výzkumu spirály mlčení}

Teorie spirály mlčení byla doposud zkoumána pomocí experimentu pouze ojediněle. Jednou z prvních autorek, která upozornila na výhody a nevýhody laboratorního experimentu v sociálních vědách, byla Leslie Kishová (1959). Výhodou je např́klad možnost kontroly narušujících proměnných, která se provádí pomocí náhodného rožrazení respondentů do kontrolní a experimentální skupiny, př́padně do různých experimentálních skupin. Studenti jsou v našem výzkumu rozděleni náhodným výběrem do čtyř skupin podle vylosovaného kódu na kartě. Zaručili jsme tak například rovnoměrné rozdělení pohlaví, oboru studia, ale i názorového rozvrstvení při diskuzi. Podle Kishové je nevýhodou experimentu jeho nepřirozenost a nízká externí validita. Jsme si vědomi toho, že naši participanti se nerozhodli sami, že budou diskutovat, a neutvořili spontánně konverzační skupinu. Přirozenost komunikace jsme se snažili zajistit tak, že účastníkům bylo vysvětleno, že pokud se nechtějí vyjádřit, pak rozmlouvat ve skupinách nemusí. Jelikož účastníci byli studenti, mohla jim situace připomínat debatu ve škole na přednáškách či seminářích, a proto nebyla až v takové míře nepřirozená. Navíc jsme stavěli participanty před diskusi aktuálních témat. Domníváme se tedy, že jsme externí validitu v rámci možností maximálně posílili, stejně jako experimentální realismus (srov. Hrbková, Chytilek 2015).

Při laboratorním experimentu musíme věnovat pozornost zkreslujícím účinkům výzkumného designu, dle Campbella (1957) jsou to: historie, zrání, testování, instrumentace, regrese, selekce a úmrtnost. Všem těmto účinkům bylo zamezeno díky krátkému trvání experimentu, používání vyškolených pomocníků, vhodnému konstruování dotazníků, nahodilým výběrem respondentů a následným náhodným rozdělením vzorku participantů.

Pomocí experimentálního designu zkoumali veřejné mínění a jeho vnímání publikem Gunter a kol. (2001). Jejich výzkum se snažil objasnit roli médií při vnímání názorového klimatu. Autoři ověřovali pomocí pretestu a postestu vliv čtení článků na vnímání laboratorních pokusů na zviŕatech. Participanti byli rozděleni do dvou skupin a polovina účastníků četla dva články o zvíŕecích právech a zbytek články o pokroku ve vědě díky testům na zviŕatech. Výsledky značí, že podle postojů prezentovaných v médiích lidé často odhadují sílu názorů $\mathrm{v}$ rámci celé společnosti.

Experimentální manipulaci použili při zkoumání teorie spirály mlčení v USA Jeffres a kol. (1999). Jejich tématem byl soudní proces se slavným afro-americkým sportovcem 
O. J. Simpsonem. Mínění ohledně jeho viny se dle výsledků této studie prokazatelně lišil v závislosti na rase. Kvótním výběrem bylo ve studii zajištěno, aby dotazování probíhalo v dostatečném množství rasově smíšených i rasově homogenních dvojic tazatel-respondent. Tazatelé respondenty žádali o vyjádření vlastního mínění a dále o souhlas s citováním jejich vyjádření (některým bylo nabídnuto citování ve výzkumné zprávě, jiným v novinách afro-americké komunity a jiným v lokální TV stanici). Dotázaní tak nevyjadřovali hypotetickou ochotu, ale reálnou ochotu nechat své mínění veřejně zaznít. Výsledky naznačují vyšší ochotu respondentů dát souhlas s veřejným citováním v rasově homogenních párech než ve smíšených. A také že $\mathrm{v}$ př́ípadě smíšených párů jsou souhlas ochotnější dávat respondenti z bílé většiny než $\mathrm{z}$ afro-americké minority. Nicméně tyto výsledky nejsou statisticky významné.

Hayes a kol. (2001) ve své studii žádal účastníky s ohledem na vnímanou podporu názorů o seřazení šesti témat a poté je nechá tato témata seřadit podruhé s ohledem na jejich ochotu o nich mluvit. Výzkum proběhl ve dvou fázích. Participanti nejprve seřadili 6 vybraných témat podle toho, jakou podporu pro svůj postoj vnímali mezi ostatními studenty Cornellovy univerzity. Zároveň měli na jiný formulář vyplnit své kontaktní údaje, pokud byli ochotní o těchto tématech diskutovat ve druhé fázi ( $90 \%$ bylo ochotno). Všichni ochotní pak byli pozváni na druhé kolo (pouze $36 \%$ dorazilo, účastníci se systematicky nijak nelišili). Ve druhém kole pak účastníci podepisovali informovaný souhlas s nahráváním diskuse, a to v místnosti, kde byl zřetelně viditelný mikrofon a nahrávací zařízení. Poté participanti seřadili šest vybraných témat podle své ochoty o nich diskutovat. Samotná diskuse se nekonala, výzkumníci ji ani neplánovali - pouze v závěrečných rozhovorech $\mathrm{s}$ účastníky ověřili, že s diskusí opravdu počítali. Ochota diskutovat vybrané téma byla prokazatelně tím vyšší, čím vyšší byla vnímaná podpora vlastního mínění.

Výzkum, který se v některých bodech shodoval s námi uskutečněným experimentem, realizovali Ho a McLeod (2008). Autoři zkoumali také rozdíly mezi diskuzí v offline a anonymním online prostředí. Studie ověrovala vliv sociálně-psychologických a kontextuálních faktorů na ochotu respondentů vyjádřit se. Kontextuálním vlivem byly dva rozdílné typy komunikace: (1) tváŕí v tvář a (2) anonymní počítačově zprostředkovaná. Za sociálně-psychologické jevy byly pokládány (1) strach z izolace, (2) vnímaná shoda mínění s okolím, (3) vnímaná názorová shoda s okolím v budoucnosti a (4) úzkost z rozmluvy. Tento design použil stejné hypotetické podmínky jako Hayes a kol. (2001). V první fázi respondenti vyplnili dotazník s demografickými otázkami, otázkami o úrovni využívání médií, o individuálních predispozicích a stanoviscích ohledně manželství dvou lidí stejného pohlaví. Poté byli ve druhé fázi rozděleni do dvou hypotetických scénářů (konverzace tváří v tvář a anonymní online diskuze). Zúčastnění byli ujištěni, že bude následovat debata, a měli dále za úkol určit na škále, jak ochotní budou vyjádřit se ohledně nepopulárních názorů $\mathrm{v}$ offline nebo anonymním online prostředí. Výsledky ukázaly, že participanti byli méně ochotní rozmlouvat v offline prostředí. Pokud účastníci vykazují vysoký strach z izolace, pak jsou o $20 \%$ méně ochotní komunikovat $\mathrm{v}$ offline prostředí ve srovnání s anonymním online. Pokud participanti vyjadřují pouze nízký strach $\mathrm{z}$ izolace, pak jejich ochota vyjádřit se je $\mathrm{v}$ anonymní online konverzaci vyšší pouze o $5 \%$.

McDevitt a kol. (2003) jako jediní autoři realizovali laboratorní experiment. Zúčastnilo se ho 48 respondentů, 24 zastánců potratů a 24 odpůrců. Výzkumníci vytvořili 12 skupin 
po šesti lidech, a to tak, že v každé skupině byli dva skuteční odpůrci potratů, dva skuteční zastánci a dva modelové (proškolení spolupracovníci výzkumníků). Modelové pak v šesti skupinách hráli zastánce potratů, a ve druhých šesti jejich odpůrce. Tím bylo dosaženo toho, že $\mathrm{v}$ polovině diskusí tvořili většinu zastánci a v polovině odpůrci potratů. Polovina těchto skupin komunikovala tváŕí $\mathrm{v}$ tvář a polovina skupin se zúčastnila počítačem zprostředkované konverzace. Pro každou kombinaci komunikačního prostředí a vybrané většiny tak existovaly vždy přesně tři diskusní skupiny. Autoři předpokládali, že (1) členové menšiny budou méně sdělovat své mínění, a to $\mathrm{v}$ obou prostř̌edích, a (2) účastníci diskusí budou hodnotit prezentované názory svých spoludiskutérů jako umírněnější v anonymním online prostředí než v komunikaci tváří $\mathrm{v}$ tvář, a to bez ohledu na členství v menšině či většině hodnotícího i hodnotitele. První hypotéza měla ve výsledcích autorů jen slabou oporu, druhá byla naopak výsledky solidně podepřena.

\section{Metody výzkumu}

V této studii prezentujeme výsledky dvou experimentů, jejichž smyslem bylo část participantů vystavit diskusi v pozici názorové menšiny, část diskusi v pozici názorové většiny a pozorovat, jak se tato situace projeví na jejich ochotě vyslovit svůj názor. První experiment se uskutečnil 26. listopadu 2012 a druhý proběhl 2. dubna 2014. Oba byly provedeny pomocí shodného designu. Prvního experimentu se zúčastnilo 42 respondentů a na druhém participovalo 43 účastníků. Zúčastnění byli studenti Západočeské univerzity v Plzni.

Všichni účastníci prošli několika fázemi výzkumu (viz Tabulka 1). První fáze výzkumu spočívala ve vyplnění dotazníku, jenž zjištoval postoje respondentů ohledně čtyř kontroverzních témat, jejich ochotu vyjádřit se, vnímanou podporu mínění ve svém okolí atd. Ve druhé fázi byla uskutečněna rozmluva tváří $\mathrm{v}$ tvář nebo internetově zprostředkovaná komunikace (polovina zúčastněných byla přidělena $\mathrm{k}$ anonymní online diskuzi (skupina 1) a polovina $\mathrm{k}$ offline konverzaci (skupina 2) podle rozřazovacího kódu, který si vylosovali. Bez ohledu na prostředí debatovali participanti ve skupinách po deseti nebo jedenácti účastnících. Ve třetí fázi byly vyplněny podruhé dotazníky, které byly zkrácenými verzemi prvního dotazníku a sloužily pro kontrolu změny názorů respondentů. Ve čtvrté fázi byli studenti opět pozorováni ve skupinách po deseti nebo jedenácti při dialogu tváŕí v tvár̆ nebo internetové diskuzi na blogu (vždy proběhl druh konverzace, kterého se doposud ještě nezúčastnili). Poslední fáze představovala opět kontrolu postojů zúčastněných pomocí zkrácené verze dotazníku.

Tabulka 1: Schéma designu výzkumu

\begin{tabular}{|c|c|c|c|c|c|c|c|c|c|}
\hline $\begin{array}{l}\text { Rozdělení } \\
\text { do skupin }\end{array}$ & 1. fáze & $\rightarrow$ & 2. fáze & $\rightarrow$ & 3. fáze & $\rightarrow$ & 4. fáze & $\rightarrow$ & 5. fáze \\
\hline 1. skupina & 1. dotazník & $\rightarrow$ & 1. diskuze OFF & $\rightarrow$ & 2. dotazník & $\rightarrow$ & 2. diskuze ON & $\rightarrow$ & 3. dotazník \\
\hline 2. skupina & 1. dotazník & $\rightarrow$ & 1. diskuze ON & $\rightarrow$ & 2. dotazník & $\rightarrow$ & 2. diskuze OFF & $\rightarrow$ & 3. dotazník \\
\hline
\end{tabular}

Zdroj: Vlastní schéma

Poznámka: ON a OFF jsou zkratky pro anonymní online a offline prostředí. 
Respondenti vyplňovali nejdříve vstupní dotazník a po každé konverzaci jsme kontrolovali v dalším dotazníku, jestli student (ne)změní svůj původní názor. Cílem výzkumu bylo také srovnání ochoty komunikovat ve dvou odlišných prostředích (offline a anonymní online). Pro kontrolu vlivu pořadí, v jakém se účastnili diskuzí, polovina zúčastněných nejprve rozmlouvala offline a druhá polovina anonymně online a druhé diskuze (4. fáze) se participanti účastnili v prostředí, ve kterém doposud neměli možnost hovořit. Anonymní online komunikace probíhala na internetovém blogu a offline debata (focus group) byla realizována participanty tváŕí v tvář v do kruhu uspořádaném sezení.

Všichni respondenti se přihlásili k participaci dobrovolně. Informace o konání obou experimentů byly zveřejněny na sociální síti www.facebook.com v otevřené skupině s názvem Západočeská univerzita. Informace byly také sdíleny na nezávislém informačním serveru Západočeské univerzity v Plzni www.dione.zcu.cz. Účastníky motivoval dle našeho úsudku nejvíce peněžní obnos, který obdrželi za participaci (150 Kč první experiment; 200 Kč druhý experiment). Pohlaví vzorku zúčastněných se ukázalo být nerovnoměrné (prvního experimentu se zúčastnilo 29 žen a 13 mužů a na druhý přišlo 23 žen a 20 mužů). V roce 2013 absolvovalo vysokou školu více žen než mužů v poměru přibližně 61 \% k 39 \% (ČSÚ 2014), což může vysvětlit částečně nerovnou účast pohlaví. Věk studentů se pohyboval od 19 do 26 let a vyznačoval se normálním rozdělením. Existuje velmi malá šance, že by se z celé univerzity přihlásilo větší množství studentů, kteří se mezi sebou znají. Pokud došlo k situaci, že se někteří participanti znali, je velmi pravděpodobné, že díky náhodnému rozdělení do skupin se tito studenti experimentu účastnili v oddělených skupinách. Nebylo však možné zaručit, že se v žádné diskusní skupině nesejde dvojice studenti̊, která se zná. V anonymním online prostředí byl tento problém ošetřen tím, že účastníci diskutovali pod přiděleným anonymním kódem. V offline prostředí jsme riziko pouze minimalizovali znáhodněním.

Studenti jsou specifická populace, která se v mnoha charakteristikách odlišuje od běžné populace - je rámována věkem, je tedy možné, že při výzkumu v běžné populaci nalezneme patrné rozdíly mezi vyjadřováním různých věkových kategorií. Studium na vysoké škole s sebou nese také určitou prestiž a kulturní kapitál. Studenti jsou vyškoleni ve využívání technologií a internetu, proto je jednoduché v této kategorii provádět počítačově zprostředkovanou diskuzi. Jak již bylo zmíněno, celá populace nemusí být v zacházení s internetem zkušená. V př́padě běžné populace bychom museli zjistit, zda všichni účastníci umí zacházet $\mathrm{s}$ technologií a nemlčí v diskuzi jenom proto, že je pro ně technologie nová a neznámá. Prostředí univerzity, kde experiment probíhal, bylo studentům známé, jsou v něm zvyklí diskutovat, tudíž využití studentů v tomto prostředí zvýšilo externí validitu a experimentální realismus (srov. Hrbková, Chytilek 2015).

Na druhou stranu, náš vzorek by se mohl v několika ohledech od běžné populace lišit. Participanti se účastnili dobrovolně, proto bychom mohli očekávat, že budou vykazovat nízkou hladinu strachu z izolace. Tento předpoklad však neplatí - pokud bychom průměrný strach z izolace přepočítali na škálu 1-5, dostali bychom průměrnou hodnotu 3,90, což je mírně vyšší hodnota ve srovnání s výsledky mezinárodního šetření, které bylo provedeno v 8 zemích a kde se průměrné hodnoty pohybovaly od 2,96 po 3,76 (Hayes a kol. 2011: 452). Dále můžeme předpokládat, že studenti budou více zvyklí diskutovat než běžná populace. To by však mělo výsledky spíše podkopávat než uměle podporovat - i studenti vykazující vyšší 
míru strachu z izolace by mohli být zvyklí hájit menšinové stanovisko a nemuseli by mít takovou tendenci v situaci menšiny mlčet. Poslední možný problém souvisí s nižším věkem studentů. V něm jsou citlivější na soudy svého okolí, jak ukazuje v experimentech s konformitou napřr. Asch (1956), a tudíž by mohli být citlivější na proces spirály mlčení než zbytek populace. Do jaké míry se studenti v procesu spirály mlčení liší nebo shodují se zbytkem populace, je obtížné posoudit, nebot' dosud nikdo nerealizoval výzkum, kde by srovnal citlivost studentů a zbytku populace na proces spirály mlčení. Pro širší zobecnění je samozřejmě nutné do budoucna do výzkumu zahrnout celou obecnou populaci.

Anonymita byla zaručena pomocí kódů (čtyřčíselných), které respondenty provázely po celou dobu trvání laboratorního experimentu. Tyto kódy byly předpřipraveny výzkumníky a účastník si svůj kód vylosoval při počáteční fázi výzkumu. Kód student vyplňoval v dotazníku, v online fázi jako přezdívku uživatele na blogu a v offline fázi byl kód respondenta náhodným losem přidělen $\mathrm{k}$ číslu místa, tzn. každému místu $\mathrm{v}$ kruhu bylo přiděleno číslo od 1 do 11 a když participant mluvil, pak na začátku promluvy vždy své číslo zmínil. Kódy byly připsány k číslu místa zúčastněných opět anonymně.

Pomocí logistické regrese jsme zjištovali, jakou roli v rámci experimentálního designu hrálo pořadí, ve kterém respondenti komunikovali ve dvou diskusních prostředích. Tzn. zda existoval rozdíl mezi ochotou vyjádřit se, pokud student nejprve diskutoval anonymně online a poté offline, než když rozmlouval nejprve offline a poté anonymně online. Regresní analýzu jsme zvolili proto, že jsme chtěli vyčíslit, o kolik se u participanta změní šance, že se vyjádří $\mathrm{v}$ prř́slušném prostředí $\mathrm{k}$ prŕśslušnému tématu, pokud experiment zahajuje debatami v anonymním online prostředí. Logistická regrese byla počíána v programu STATA 12. Druhá metoda, $\chi^{2}$ test, již nekontroloval design, ale ověřoval statistickou významnost rozdílů mezi vyjadřováním mínění $\mathrm{v}$ offline a anonymním online prostředí a při zapojení proměnných strach z izolace a zastávaný postoj.

\section{Témata}

V každém ze dvou experimentů jsme zjištovali postoje participantů ohledně čtyř témat. V prvním experimentu byla témata následující: (1) Měla by se zpř́snit kritéria pro vyplácení sociálních dávek Romům? Podle Klíčové (2004) jsou Romové nejčastěji pokládáni v ČR za etnickou menšinu. Jejich časté vyloučení z trhu práce je spjato $\mathrm{s}$ chudobou a zapříčiněno nízkou vzdělanostní a kvalifikační úrovní př́slušníků romské komunity. Přístup k legálním zdrojům obživy se často omezuje právě na sociální dávky. (2) Je príijatelné, aby se Vladimír Franz stal prezidentem ČR? Po problémech se zvolením prezidenta v roce 2003 a 2008 bylo přistoupeno k př́mé volbě hlavy státu (Koudelka 2011). Vladimír Franz byl považován částí veřejnosti za kontroverzního, protože měl na celém obličeji tetování. (3) Měla by být v ČR úplně legalizována marihuana? Platná právní úprava (Zákon č. 167/1998 Sb.) zakazuje nepovolené držení omamných látek, a stanovuje tak za neoprávněné držení různě odstupňované sankce (Sotolár 2003). (4) Je př́nosné pro obyvatele ČR, že KSČM dosáhla velmi dobrých výsledků v krajských ř́ijnových volbách 2012? Proti výsledkům krajských voleb se uskutečnilo mnoho demonstrací. Jeden z výrazných protikomunistických protestů proběhl mezi studenty koncem roku 2012 a začátkem roku 2013 na jihu Čech ve formě štafetové hladovky. 
Ve druhém experimentu byli účastníci dotazováni: (1) Podporovali byste zásah české armády společně s ostatními členy NATO na Krymu? Jedná se o konflikt Ukrajina-Rusko, což v době konání experimentu bylo velmi diskutované téma. (2) Je podle vás vhodný a spravedlivý návrh na doplnění peněz ve státním rozpočtu pomocí zvýšení daní pro živnostníky? $\mathrm{S}$ tímto návrhem přišli odboráři z Asociace samostatných odborů. (3) Třetí téma jsme již použili v prvním experimentu a nyní zopakovali: Měla by být v ČR úplně legalizována marihuana? (4) Pokud člověk požádá v případě nesnesitelných bolestí či nevyléčitelných chorob o eutanázii, měla by mu být poskytnuta?

V analýze dat však nevyužíváme všechna výše zmíněná témata. Pro konstrukci proměnných (viz dále) jsme totiž potřebovali, aby k tématu byla jasně vyprofilovaná většina, tedy aby jedna názorová pozice měla mezi účastníky nadpoloviční většinu zastánců. Ke každému tématu bylo možné uvést souhlasné nebo zamítavé stanovisko a také odpovědět „nevím“. Za jasně vyprofilovanou většinu bereme takový postoj, který má více zastánců, než kolik tvoří součet odpovědí u zbylých dvou možností. Jelikož se experimentů účastnilo 42 a 43 participantů, bylo třeba, aby se k postoji přihlásilo alespoň 22 zastánců, aby byl požadavek na jasně vyprofilovanou většinu naplněn.

Tyto požadavky naplnilo pět témat: dávky Romům, prezident Franz, úspěch KSČM, anexe Krymu a eutanázie. Po zvážení jsme zařadili do analýzy ještě další dvě témata - legalizaci marihuany z prvního experimentu a daně živnostníků. Obě témata jen těsně nesplnila kritérium 22 zastánců jednoho postoje - zastánců legalizace marihuany bylo v prvním dotazování 21, v dalších 22 a více; také odpưrců daní živnostníků bylo v prvním dotazování 21 a v dalších 25 a více. Navíc, v prrípadě obou témat bylo v prvním dotazování 10 resp. 19 odpovědí „nevím“, tím pádem opačný postoj zastávala vždy výrazná menšina. Podle našeho názoru i tato dvě témata splňují požadavek jasně vyprofilované většiny. Nevyužíváme tak jen téma legalizace marihuany z druhého experimentu. Odpověd' „nevím“ zde volilo naprosté minimum participantů, avšak zastánců i odpůrců byl v prvním dotazování naprosto shodný počet: 20 . Ani v dalších dotazováních zastánci legalizace drtivě nepřevážili. Věříme, že vyřazené téma může přinést zajímavé odpovědi na vhodně zvolené výzkumné otázky, ale nehodí se pro řešení naší výzkumné otázky:

O1: Jak se liši vyjadřování mínění zastánců menšinového a většinového postoje v offline $a v$ anonymnim online prostředi?

\section{Proměnné a hypotézy}

Závisle proměnnou je vyjádření se $v$ diskusi, tedy to, zda se v offline a anonymním online prostředí účastníci vyjadřovali, nebo mlčeli. V obou prostředích jsme zaznamenávali, zda se př́slušný participant alespoň jednou vyjádřil k prŕslušnému tématu. Závisle proměnná je tedy binární, pro každého účastníka prvního experimentu máme sadu 8 závisle proměnných (4 témata ve 2 diskusních prostředích), pro každého účastníka druhého experimentu pak sadu 6 závisle proměnných (3 témata ve 2 prostředích). Celkem tak měli účastníci 594 př́ležitostí k vyjádření ${ }^{2}$, z toho $193 x$ mlčeli (32,5 \%) a 401x se alespoň jednou k tématu vyjádřili (67,5\%).

$2 \quad 8 * 42+6 * 43=594$ 
Klíčová nezávisle proměnná většinový/menšinový postoj nám říká, zda se participant ohledně př́islušného tématu klonil během celého experimentu k většinovému, nebo menšinovému postoji, nebo mezi nimi osciloval. V prvním dotazníku jsme zaznamenali názor účastníků na všechna diskutovaná témata na škále 1-5, kde 1 a 2 byl odstupňovaný nesouhlas, 3 byla odpověd' „nevím“ a 4 a 5 byl odstupňovaný souhlas. Pro účely analýzy jsme kategorie 1 a 2 sloučili do jedné jako nesouhlas. Podobně jsme kategorie 4 a 5 sloučili jako souhlas. Pak jsme jako většinovou označili tu názorovou pozici, kterou zastávalo alespoň 22 participantů (v prŕípadě legalizace marihuany a daní živnostníků alespoň 21). Opačnou pozici jsme označili jako menšinovou, a to i včetně odpovědí „nevím“. Pak jsme sledovali, zda i v následných dvou dotazováních zaujme participant shodný postoj, nebo jiný. Pokud zastával ve všech třech dotazováních většinový postoj, kódovali jsme jej jako 1 - stabilní většinu. Pokud zastával ve všech třech dotazováních menšinový postoj nebo nevěděl, kódovali jsme jej jako 2 - stabilní menšinu. Pokud v některých dotazováních označil participant většinový postoj a v jiných menšinový nebo nevěděl, kódovali jsme jej jako 0 - nestabilní. Celkem jsme mohli stabilitu postoje hodnotit ve 297 př́ipadech ${ }^{3}$, přičemž nestabilních případů bylo 70 (23,6 \%), stabilní většinu jsme identifikovali 169x (56,9\%) a stabilní menšinu 58x $(19,5 \%)$.

Další nezávisle proměnná - diskusní prostředi - nám říká, zda př́islušná diskuse proběhla v offline, nebo anonymním online prostředí. Aplikujeme zde within-person design, tj. každý participant diskutoval př́slušné téma dvakrát, jednou anonymně online a jednou offline, proto jsou diskusní prostředí v datech zastoupena naprosto rovnoměrně. Pomocí této proměnné sledujeme, zda v některém studovaném prostředí participanti projevují své mínění častěji než ve druhém. Dále pomocí této proměnné elaborujeme studované vztahy mezi vyjádřením se v diskusi na jedné straně a strachem z izolace a zastávaným postojem na straně druhé.

Pořadi je kontrolní proměnná, pomocí které odlišujeme mezi sebou dvě skupiny respondentů (viz Tabulka 1): 1. skupina diskutovala nejprve offline a poté anonymně online $(54,1 \%) ; 2$. skupina diskutovala nejprve anonymně online a poté offline $(45,9 \%)$. Proměnná nám tedy $\mathrm{v}$ analýze bude ř́kat, jaký je efekt toho, že participant téma poprvé diskutoval anonymně online (skupina s vyšším pořadovým číslem témata nejprve diskutuje anonymně online a efekt bude $\mathrm{v}$ analýze připisován právě vyššímu pořadovému číslu). Srovnáním komunikačního chování participantů v těchto dvou skupinách zjišt’ujeme, zdali má vliv pořadí komunikačních prostředí na ochotu vyjádřit se.

Další kontrolní proměnná je strach z izolace $(\mathrm{Min}=10 ; \mathrm{Max}=25$; Průměr $=19,5 ; \mathrm{SD}=3,3)$, který jsme v úvodní teoretické konceptualizaci vymezili jako trvalý osobnostní rys. Strach z izolace jsme zjišt'ovali $\mathrm{v}$ dotazníku pomocí souhlasu na pětibodové škále (1=rozhodně nesouhlasí, 3=ani souhlas ani nesouhlas nebo neví, 5=rozhodně souhlasí) s pěticí výroků: (1) „Je pro mě strašné pomyslet, že nebudu pozván/a na přátelské setkání od lidí, které znám.“ (2) „Jedna z nejhorších věcí, které se mi mohou stát, je být vyloučen lidmi, které znám.“ (3) „Vadilo by mi, kdyby se mnou nikdo nechtěl trávit čas.“ (4) „Nemám rád pocit, že jsem vynechán/a z přátelských setkání, párty a jiných sešlostí.“(5) „Je pro mě důležité zapadnout

4 témata $* 42$ účastníků +3 témata $* 43$ účastníků $=297$ 
do skupiny, se kterou fyzicky jsem." Pro účel $\chi^{2}$ testu byla proměnná strach z izolace kategorizována do dvou skupin: respondent vyjadřuje nižší míru strachu z izolace (0; skóre 10-19 na původní škále; 52,4 \%) a respondent vyjadřuje vyšší míru strachu z izolace (1; skóre 20-25 na původní škále; 47,6 \%). Strach z izolace byl zjišs'ován pouze v prvním experimentu.

Měření strachu z izolace pomocí výše uvedené pětice výroků vyvinul Hayes s kolegy (2011). Hodlali zachytit strach z izolace jako trvalý osobnostní rys, přičemž se chtěli vyhnout jeho záměně za stydlivost či komunikační ostýchavost, která se strachem z izolace nesouvisí. Dále usilovali o nízký počet položek a srozumitelnost, aby byla škála využitelná i v dotazování pomocí telefonu. Cíle se jim podařilo dosáhnout, jak ukázalo srovnání s konkurenčními způsoby měření strachu z izolace (Ho, McLeod 2008; Scheufele a kol. 2001) a provedené testy pomocí konfirmační faktorové analýzy. Škála byla dále použita ve dvou mezinárodních výzkumech, které zkoumaly proces spirály mlčení v celkem deseti zemích včetně USA, Číny a Ruska (Hayes a kol. 2011; Matthes a kol. 2012).

Tedy v reálné situaci zjišt’ujeme vztah mezi vyjádřením vlastního postoje v dotazníku a chováním v diskuzích (vyjadřuje mínění/mlčí) při zapojení proměnných (1) strach z izolace, (2) prostředí diskuse (offline/anonymní online) a (3) pořadí. Proces spirály mlčení představuje nátlak na menšinovou skupinu, která se obává vyjádřit své stanovisko a raději se k tématu nevyjadřuje. Předpokládáme tedy, že:

H1: Participanti, kteři zastávají menšinový postoj, budou v diskuzích mlčet častěji než participanti, kteři zastávaji většinový postoj.

H2: Všichni participanti budou ochotnějši vyjádřit své mínění v anonymním online $n e z ̌ v$ offline prostredí.

H3: Vztah menšinového postoje a mlčeni bude platit pouze pro participanty vyjadřující vyšši míru strachu z izolace. Participanti vyjadřující nižši míru strachu z izolace budou své mínění vyjadřovat stejně často bez ohledu na to, zda zastávají většinový nebo menšinový postoj.

\section{Výsledky}

Vývoj postoje byl sledován pomocí opakovaného dotazování v průběhu laboratorního experimentu. V Tabulce 2 můžeme vidět podle jednotlivých témat, kolik participantů mělo ve všech třech dotazováních většinový postoj, kolik mělo stabilně menšinový postoj a kolik kolísalo - v některém dotazování uvedli většinový a v některém menšinový postoj nebo nevěděli. Nejstabilnější byly postoje ohledně zpřísnění pravidel pro vyplácení dávek Romům (přes 95 \%) a nejméně stabilní byly postoje ohledně zdanění živnostníků $(67,5 \%$ ). Pokud v dalším textu budeme porovnávat zastánce většinového postoje se zastánci menšinového, budou z těchto analýz vynecháni participanti s nestabilním postojem. Je proto důležité, že i v nejméně stabilním tématu je participantů s nestabilním postojem jen $32,6 \%$.

Vliv kontrolní proměnné pořadí byl zkoumán pomocí logistické regrese. Jako závisle proměnnou využíváme indikátor, zda se participant během diskuse v příslušném prostředí k př́slušnému tématu vyjádřil. Vztah pořadí a vyjádření se kontrolujeme pro prostředí a téma diskuse. Výsledky v Tabulce 3 nám tedy říkají, zda náhodně vylosované pořadí dis- 
kusních prostředí nějak ovlivnilo tendenci participantů se k tématu vyjádřit. Můžeme vidět, že pořadí prostředí nemá téměř žádný vliv na vyjadřování se respondentů.

Tabulka 2: Stabilita postojů postupně vyjádřených ve třech po sobě jdoucích dotazováních dle jednotlivých témat - řádková procenta (marginální četnosti) $\left(\mathrm{N}_{1}=42, \mathrm{~N}_{2}=43\right.$ )

\begin{tabular}{|c|c|c|c|c|}
\hline Témata & Nestabilní & Stabilní většina & Stabilní menšina & Celkem \\
\hline \multicolumn{5}{|l|}{ 1. experiment } \\
\hline Romové & $4,8 \%$ & $83,3 \%$ & $11,9 \%$ & $100 \%(42)$ \\
\hline Vladimír Franz & $26,2 \%$ & $47,6 \%$ & $26,2 \%$ & $100 \%(42)$ \\
\hline Legalizace marihuany & $23,8 \%$ & $42,9 \%$ & $33,3 \%$ & $100 \%(42)$ \\
\hline KSČM & $28,6 \%$ & $59,5 \%$ & $11,9 \%$ & $100 \%(42)$ \\
\hline \multicolumn{5}{|l|}{ 2. experiment } \\
\hline Konflikt RUS-UA & $27,9 \%$ & $48,8 \%$ & $23,3 \%$ & $100 \%(43)$ \\
\hline Daně živnostníků & $32,6 \%$ & $41,9 \%$ & $25,6 \%$ & $100 \%(43)$ \\
\hline Eutanázie & $20,9 \%$ & $74,4 \%$ & $4,7 \%$ & $100 \%(43)$ \\
\hline
\end{tabular}

Zdroj: Vlastní šetření

Poznámka: $Z$ analýzy vynecháváme téma legalizace marihuany ve druhém experimentu, bližší vysvětlení viz sekce Témata, kde také uvádíme podrobnější popis témat.

Tabulka 3: Logistická regrese vlivu první diskuse v anonymním online prostředí na šanci, že se participant vyjádří v prríslušném prostředí $\mathrm{k}$ prríslušnému tématu - logity (standardní chyby) $\left(\mathrm{N}_{1}=42, \mathrm{~N}_{2}=43\right.$ )

\begin{tabular}{|c|c|c|c|c|}
\hline Témata & \multicolumn{2}{|c|}{ Offline } & \multicolumn{2}{|c|}{ Online } \\
\hline \multicolumn{5}{|l|}{ 1. experiment $(\mathrm{N}=42)$} \\
\hline Romové & $-1,030$ & $(0,649)$ & $-0,100$ & $(1,449)$ \\
\hline Vladimír Franz & 0,288 & $(0,659)$ & $-1,946$ & $(1,146)^{\dagger}$ \\
\hline Legalizace marihuany & 0,038 & $(0,630)$ & $-0,125$ & $(0,725)$ \\
\hline KSČM & 0,038 & $(0,630)$ & $-0,125$ & $(0,725)$ \\
\hline \multicolumn{5}{|l|}{ 2. experiment $(\mathrm{N}=43)$} \\
\hline Konflikt RUS-UA & $-0,151$ & $(0,619)$ & $-1,172$ & $(0,790)$ \\
\hline Daně živnostníků & 1,012 & $(0,635)$ & $-0,114$ & $(0,667)$ \\
\hline Eutanázie & 0,773 & $(0,640)$ & 1,281 & $(1,164)$ \\
\hline
\end{tabular}

Zdroj: Vlastní šetření

Poznámka: $\uparrow \mathrm{p}<0,1$; ostatní koeficienty jsou statisticky nevýznamné. Tabulka zachycuje klícový nestandardizovaný koeficient efektu pořadí odhadnutý pro stejnou regresní rovnici ve 14 různých kontextech (všechny kombinace 7 témat a 2 diskusních prostředí), v tabulce nejsou uvedeny konstanty rovnice pro tyto různé kontexty. Pořadi je v regresní rovnici jediná vysvětlující proměnná.

Pouze v jediné ze 14 sledovaných kombinací prostředí a tématu je vliv pořadí alespoň marginálně statisticky významný - jde o téma vhodnosti kandidatury Vladimíra Franze na prezidenta ČR. Výsledek znamená, že pokud participant diskutoval toto téma poprvé anonymně online, tak měl v online prostředí menší tendenci se vyjadřovat, než když téma nejprve disku- 
toval offline. Ti, kteří anonymní online diskusí začínali, se online vyjadřovali v $75 \%$ př́padů. Ti, kteř́ nejprve diskutovali offline, se posléze $\mathrm{v}$ anonymním online prostředí vyjadřovali v $95 \%$ prŕpadů. Byt' můžeme v Tabulce 3 najít ještě pět dalších koeficientů, jejichž absolutní hodnota je větší než 0,7 , ani tyto nejsou statisticky významné. Ale především zmiňme, že těchto šest věcně zajímavých koeficientů nevytváŕí žádný systematický vzorec.

Podle výsledků se nezdá, že by pořadí diskusních prostředí v našem experimentu ovlivnilo chování participantů. Znamená to, že v jednotlivých prostředích se zúčastnění vyjadřovali přibližně stejně často, at' to bylo první kolo diskuzí, nebo již předtím ta samá témata probírali v odlišném prostředí. Pokud to usnadní organizaci, je možné v př̌šstím využití experimentálního designu nejprve nechat participanty komunikovat $\mathrm{v}$ jednom a poté všechny $\mathrm{v}$ odlišném prostředí. Navíc to dává více možností jak měnit složení debatních skupin během experimentu - v našem designu mohl student rozmlouvat pouze s tou polovinou participantů, která stř́́dala prostředí ve stejném pořadí. Pokud nebudeme kontrolovat pořadí diskuzních prostředí, má participant šanci konverzovat se všemi účastníky stejného experimentu.

Nyní můžeme prověřit platnost našich hypotéz a můžeme hledat odpovědi na naši výzkumnou otázku - budeme tak činit pomocí $\chi^{2}$ testu. Pokud prověříme první hypotézu, prostý vztah zastávaného postoje a tendence vyjádřit se, naše výsledky bez problémů podpoří teorii spirály mlčení. Stabilní většina se vyjádřila v 72,8 \% př́ípadů z 338 možných, stabilní menšina jen v 56,0 \% př́padů ze 116 možných - tento rozdíl je nepochybně věcně významný a je významný i statisticky $\left(\chi^{2}(1)=10,8\right.$; Fischerův exaktní test: $\left.\mathrm{p}=0,001\right)$. Podobně prostý test druhé hypotézy - o vlivu diskusního prostředí na ochotu vyjádřit se - podporuje předpoklady McDevitta a kol. (2003) a Ho a McLeoda (2008). V anonymním online prostředí se participanti vyjadřují v 81,5\% př́ležitostí z 297 možných, zatímco v offline prostředí jen v 53,5 \% př́ležitostí z 297. Tento rozdíl je jednoznačně věcně významný a je významný i statisticky $\left(\chi^{2}(1)=54,2\right.$; Fischerův exaktní test: $\left.\mathrm{p}<0,001\right)$.

Tabulka 4 ukazuje i výsledky pro vzájemnou kontrolu prostředí a postoje. Je z ní patrné, že participanti se $\mathrm{v}$ anonymním online prostředí častěji vyjadřovali bez ohledu na zastávaný postoj. Zároveň se v obou prostředích více vyjadřovali zastánci většinového postoje - avšak tento rozdíl je statisticky významný pouze $\mathrm{v}$ anonymním online prostředí. Rozdíl $\mathrm{v}$ offline prostředí mezi stabilní většinou a stabilní menšinou je 12,5 procentního bodu, což není zanedbatelné, ale statisticky významné to není. Tento výsledek je mírně překvapivý - podle postoje bychom spíše čekali výrazný rozdíl ve vyjádření v offline prostředí. Proč $\mathrm{k}$ tomu nedošlo, mohlo být dáno také způsobem měření vyjadřování mínění $\mathrm{v}$ diskusi tváríi v tvář. Jednak byla délka diskuse jednoho tématu omezena na cca 15 minut - možná by se vyjádřilo více zastánců většinového postoje, kdyby dostali více času. Také byli pozorovatelé instruováni, aby pokývání, zamručení či jiné neverbální vyjádření nebrali v úvahu a zaznamenávali pouze jasná verbální vyjádření mínění. S tím souvisí další možný důvod - bývá obvyklé verbálně vyjadřovat protichůdná nebo alespoň doplňující stanoviska, souhlas se obvykle vyjadřuje stručně a často neverbálně. A je otevřenou otázkou, jak tato neverbální vyjádření vnímají účastníci debaty, jak formují jejich představu o názorovém klimatu. Na tuto otázku nemůžeme poskytnout odpověd' - naše data zachycují, jak se mění vnímání názorového klimatu, ale nezachycují neverbální reakce.

Nyní se zaměřme na poslední hypotézu - o strachu z izolace. Pokud bychom sledovali př́mý vliv strachu na vyjádření se, vztah se ukáže jako slabý a statisticky nevýznamný. 
Osoby vyjadřující nižší míru strachu vyjádřily své mínění v 67,6 \% případů ze 176 . Osoby vyjadřující vyšší strach dokonce v 73,1 \% př́padů ze 160 . Není třeba ani ověřovat statistickou významnost - osoby vyjadřující vyšší míru strachu by měly vyjadřovat své mínění méně a ne více. Máme tedy potvrzeno, že v našem experimentu strach z izolace není př́mou příčinou tendence vyjádřit se. Strach z izolace ale nemá fungovat podle teorie spirály mlčení takto př́močaře.

Tabulka 4: Vliv postoje a prostředí diskuze na vyjádření mínění, nebo mlčení - sloupcová procenta (marginální četnosti) $(\mathrm{N}=454)$

\begin{tabular}{|l|c|c|c|c|}
\hline & \multicolumn{2}{|c|}{ Online } & \multicolumn{2}{c|}{ Offline } \\
\hline & Stabilní věłšina & Stabilní menšina & Stabilní většina & Stabilní menšina \\
\hline Vyjádřil/a se & $89,9 \%$ & $69,0 \%$ & $55,6 \%$ & $43,1 \%$ \\
\hline Mlčel/a & $10,1 \%$ & $31,0 \%$ & $44,4 \%$ & $56,9 \%$ \\
\hline Celkem & $100 \%(169)$ & $100 \%(58)$ & $100 \%(169)$ & $100 \%(58)$ \\
\hline
\end{tabular}

Zdroj: Vlastní šetření

Poznámka: V situaci většiny anebo menšiny se mohl jeden participant ocitnout celkem osmkrát nebo šestkrát; každý debatoval ve dvou diskusních prostředích, v každém o čtyřech (1. experiment) nebo třech (2. experiment) tématech s vyprofilovanou většinou. $V$ tabulce uvádíme pouze údaje o respondentech, kteří během experimentu nezměnili svůj postoj k př́slušnému tématu. Statistická významnost rozdílů jednotlivých srovnání: Celá tabulka $\chi^{2}(3)=66,3(p<0,001 ; N=454)$; Menšina: online vs. offline $\chi^{2}(1)=7,9$ (Fischerův exaktní test: $p=0,009 ; \mathrm{N}=116$ ); Většina: online vs. offline $\chi^{2}(1)=50,2$ (Fischerův exaktní test: $\mathrm{p}<0,001 ; \mathrm{N}=338$ ); Online: menšina vs. většina $\chi^{2}(1)=13,0$ (Fischerův exaktní test: $\mathrm{p}<0,001 ; \mathrm{N}=227$ ); Offline: menšina vs. většina $\chi^{2}(1)=2,7$ (Fischerův exaktní test: $\mathrm{p}=0,127 ; \mathrm{N}=227$ ).

Hypotéza H3 v souladu s teorií spirály mlčení př́mý vliv nepředpokládá - strach z izolace má pouze specifikovat podmínky. Vliv postoje na vyjádření se má platit pouze pro osoby vyjadřující vyšší strach z izolace. Pokud podmínka vyššího strachu neplatí, neměli bychom pozorovat rozdíl mezi zastánci většinového a menšinového postoje ve vyjadřování jejich mínění. A přesně v tomto smyslu vyznívá Tabulka 5. Pouze u respondentů vyjadřujících vyšší míru strachu z izolace můžeme pozorovat věcně a statisticky významné rozdíly ve vyjadřování mínění. Naše výsledky tak podporují zdůvodnění Noelle-Neumannové, proč spirála mlčení funguje.

Pokud bychom Tabulku 5 dále elaborovali pomocí prostředí diskuse, pozorované vztahy se ještě posílí. U jedinců vyjadřujících nižší míru strachu z izolace je v anonymním online prostředí tendence vyjadřovat mínění shodná (většinový postoj 84,6 \%, menšinový postoj $82,6 \%$, Fischerův exaktní test: $\mathrm{p}=1,000, \mathrm{~N}=75)$. V komunikaci tváří v tvář je sice výraznější rozdíl v tendenci vyjadřovat se, ale rozdíl stále není statisticky významný (většinový postoj 57,7 \%, menšinový postoj 43,5 \%, Fischerův exaktní test: $p=0,319, \mathrm{~N}=75$ ). Levou část Tabulky 5 tedy tyto výsledky replikují - rozpracování vlivu nižšího strachu z izolace pomocí prostředí diskuse nic nového nepřineslo. Snad jen nyní lépe rozumíme tomu, kde se především bere rozdíl mezi zastánci většinového a menšinového postoje - je to v diskusi tváří v tvář. Avšak jde o statisticky nevýznamný rozdíl, který by bylo třeba potvrdit na mnohem větším vzorku. 
Tabulka 5: Vliv postoje a strachu z izolace na vyjádření mínění - sloupcová procenta (marginální četnosti) (N=266)

\begin{tabular}{|l|c|c|c|c|}
\hline & \multicolumn{2}{|c|}{ Nižší strach z izolace } & \multicolumn{2}{c|}{ Vyšší strach z izolace } \\
\hline & Stabilní menšina & Stabilní většina & Stabilní menšina & Stabilní většina \\
\hline Vyjádřil/a se & $63,0 \%$ & $71,2 \%$ & $50,0 \%$ & $79,4 \%$ \\
\hline Mlčel/a & $37,0 \%$ & $28,9 \%$ & $50,0 \%$ & $20,7 \%$ \\
\hline Celkem & $100 \%(46)$ & $100 \%(104)$ & $100 \%(24)$ & $100 \%(92)$ \\
\hline
\end{tabular}

Zdroj: Vlastní šetření

Poznámka: Strach z izolace jsme měřili pouze v 1. experimentu. V situaci většiny anebo menšiny se mohl jeden participant ocitnout celkem osmkrát (každý debatoval ve dvou diskusních prostředích, v každém vždy o čtyřech tématech). Do výsledků jsou zahrnuti pouze participanti se stabilním postojem. Statistická významnost rozdílů jednotlivých srovnání: Celá tabulka $\chi^{2}(3)=9,3(p=0,025 ; \mathrm{N}=266)$; Nižší strach z izolace: menšina vs. většina $\chi^{2}(1)=$ 1,0 (Fischerův exaktní test: $\mathrm{p}=0,344 ; \mathrm{N}=150$ ); Vyšší strach $\mathrm{z}$ izolace: menšina vs. většina $\chi^{2}(1)=7,7$ (Fischerův exaktní test: $\mathrm{p}=0,008 ; \mathrm{N}=116$ ); Menšina: nižší strach vs. vyšší strach $\chi^{2}(1)=1,1$ (Fischerův exaktní test: $\mathrm{p}=0,318$; $\mathrm{N}=70$ ); Většina: nižší strach vs. vyšší strach $\chi^{2}(1)=1,8$ (Fischerův exaktní test: $\mathrm{p}=0,247 ; \mathrm{N}=196$ ).

Také elaborace pravé části Tabulky 5 replikuje zjištění - mezi jedinci, kteří vyjadřují vyšší míru strachu z izolace, mají větší tendenci vyjadřovat své mínění osoby, které zastávají většinový postoj, a to bez ohledu na prostředí diskuse. Při anonymní online komunikaci se vyjadřují téměř všichni s většinovým postojem, ale jen dvě třetiny participantů s menšinovým (většinový postoj 91,3 \%, menšinový postoj 66,7 \%, Fischerův exaktní test: p = 0,049, N = 58). Při komunikaci tváří v tvář vyjadřují mínění dvě třetiny osob s většinovým postojem a pouhá jedna třetina osob s menšinovým postojem (většinový postoj 67,4 \%, menšinový postoj 33,3 \%, Fischerův exaktní test: $\mathrm{p}=0,047, \mathrm{~N}=58$ ). Jinými slovy, naše dosavadní zjištění se nezmění, ani pokud vezmeme v úvahu prostředí diskuse. Anonymní online prostředí sice zvyšuje pravděpodobnost, že participant vyjádří své mínění, ale tuto pravděpodobnost zvyšuje zhruba stejně pro různé kombinace strachu z izolace a zastávaného postoje (o cca 30 procentních bodů).

\section{Diskuse a závěr}

Odpověd' na naši výzkumnou otázku je poměrně jednoduchá - jak zastánci menšinového, tak zastánci většinového postoje vyjadřují s větší pravděpodobností své mínění v anonymním online prostředí. Podpořili jsme tím výsledky McDevitta a kolektivu (2003) a Ho a McLeoda (2008), kteří předpokládali, že anonymní online prostředí podpoří vyjadřování mínění. Přidaná hodnota našeho výzkumu tkví v tom, že jsme vyloučili interakci diskusního prostředí se strachem z izolace a zastávaným postojem: žádné ze dvou zkoumaných prostředí efekt strachu a efekt zastávaného postoje ani neumocňuje, ani neinhibuje, což dokládá naše elaborace v závěru analýzy. Jedinci, kteří vykazovali nižší míru strachu z izolace, měli shodnou tendenci vyjadřovat mínění, at' už zastávali většinový, nebo menšinový postoj (v anonymním online prostředí samozrrejmě vyjadřovali zastánci obou postojů své mínění výrazně častěji). U jedinců, kteří vykazovali vyšší míru strachu z izolace, závisela tendence vyjadřovat mínění na jejich postoji - ti s většinovým postojem vyjadřovali své mínění výrazně častěji než ti s menšinovým postojem (v anonymním online prostředí opět vyjadřovali zastánci obou 
postojů své mínění výrazně častěji než v offline prostředí, ale rozdíl mezi zastánci většinového a menšinového postoje byl $\mathrm{v}$ obou prostředích stejný). Efekt prostředí se nám jeví jako aditivní - anonymní online prostředí zvyšuje zhruba o 30 procentních bodů pravděpodobnost, že osoba vyjádří své mínění, a to bez ohledu na zastávaný postoj a vyjadřovanou míru strachu z izolace.

Ani další výsledky nebyly př́liš překvapivé. Podpořili jsme zdůvodnění Noelle-Neumannové, proč spirála mlčení funguje - osoby, které mají strach ze sociální izolace, méně vyjadřují své mínění, pokud zastávají postoj, který je momentálně menšinový. To však není vůbec banální výsledek, nebot' se nám podařilo podpořit jádro teorie na datech, která krom jiného zaznamenávala chování participantů. Drtivá většina výzkumů spirály mlčení dosud využívala pouze hypotetické míry ochoty vyjadřovat mínění, výzkumy zahrnující míry reálné komunikační aktivity jsou ojedinělé. A pokud víme, dosud nikdo na takových ojedinělých datech neprokázal, že vliv zastávaného postoje na vyjádření mínění platí pouze pro jedince s vyšším strachem z izolace, což přsesně předpokládá teorie spirály mlčení.

Tento náš výsledek je důležitý, protože v úvodu zmíněný Bodor (2012) velice přesvědčivě zpochybnil výzkum spirály mlčení založený na hypotetických měrách ochoty vyjadřovat mínění. Nemyslíme si rozhodně, že bychom celou tradici zachránili dvěma experimenty, kterými prošlo celkem 85 studujících. Je to ale důležitý kamínek do mozaiky, která zatím ukazuje, že výsledky založené na hypotetických otázkách nejsou zásadně chybné. Dokonce i sám Bodor získal výsledky, které nejsou s teorií a hypotetickými měrami v rozporu. Ale přesto, a navzdory našim výsledkům, pokládáme za důležité úsilí experimentálně ověřovat výsledky, které jsou dosud podpořené pouze hypotetickými měrami.

V Tabulce 5 jsme přinesli ještě jeden věcně zajímavý výsledek, který je bohužel statisticky nevýznamný. Nejmenší tendenci se vyjadřovat mají jedinci ze stabilní menšiny vykazující vyšší strach z izolace (50 \%). Poté následují jedinci vykazující nižší strach z izolace, nejprve stabilní menšina (63 \%) a pak stabilní většina (71 \%). A konečně, největší tendenci vyjadřovat se mají jedinci ze stabilní většiny vykazující vyšší hladinu strachu z izolace (79 \%). Zdá se, jako by základní tendence vyjadřovat se byla dána menšinovým nebo většinovým postojem, který umocňuje strach z izolace - bojácní členové většiny se vyjadřují ještě více než zbytek většiny a bojácní členové menšiny mlčí ještě více než ostatní členové menšiny. Byt’ tyto výsledky může potvrdit jen další výzkum založený na dostatečně velkém vzorku, kde bude možné prokázat statistickou významnost, dodejme, že výsledky jsou konzistentní s teorií. Noelle-Neumannová (1993) předpokládala, že se snažíme vyjadřovat názory hodnocené jako správné, jelikož se obáváme sankce ve formě sociální izolace, pokud vyjádříme názory hodnocené jako špatné. Tradičně je to interpretováno tak, že jedinci, kteří se více obávají sociální izolace, mlčí, pokud mají menšinový postoj. Naše výsledky naznačují, že by symetricky k tomu mohlo platit, že jedinci, kteří se více obávají sociální izolace, by mohli častěji vyjadřovat svůj postoj, pokud by byl většinový, aby dali svému okolí najevo, že stojí na té správné straně př́ípadného sporu.

Na základě prostudované literatury jsme očekávali, že participanti bud’ budou mlčet, nebo vyjádří mínění $\mathrm{v}$ souladu se svým postojem, ale někteří participanti $\mathrm{v}$ diskusích vyjadřovali mínění, které bylo v rozporu s postojem, který opakovaně zaznamenali v dotazníku. Podobně jako v Aschově (1956) laboratoři veřejně označili participanti pod skupinovým tlakem evidentně špatnou úsečku, v našem experimentu účastníci projevili v diskuzi zcela opačný názor 
oproti tomu, který v dotazníku před debatou a následně i v dotazníku po diskuzi označili za svůj vlastní. Tito lidé si své menšinové postoje ponechali i přes to, že se veřejně vyjádřili jako většina. A platilo to i naopak: někteří konzistentní zastánci většinového postoje v diskusích vyjadřovali menšinové mínění.

S možností, že by participanti popírali svůj postoj vyjádřeným míněním, nepracovala ani Noelle-Neumannová, která na Aschovy experimenty odkazovala, když zdůvodňovala funkci strachu z izolace (Noelle-Neumannová 1977, 1993). Krom Neuwirtha a kol. (2007) již žádní další výzkumníci s popíráním postoje nepracovali. Domníváme se, že opominutí popírání postoje plyne z faktu, že drtivá většina výzkumů spirály mlčení použivala hypotetické míry ochoty vyjádřit se. Noelle-Neumannová ani další výzkumníci nikde explicitně neuvádějí, že by uvažovali o možnosti zařadit do hypotetické otázky na vyjádření mínění i možnost s popřením postoje. Může se totiž zdát, že by taková otázka byla velmi sociálně citlivá a že by respondenti nepřiznali popření vlastního postoje. Tento dojem je však mylný, Neuwirth a kol. (2007) tendenci k popírání úspěšně změřili i pomocí hypotetické otázky. Požádali respondenty, aby na jedenáctibodové škále označili, jak moc je pravděpodobné, že by byli v situaci názorové menšiny a zároveň uvedli nebo podpořili většinové mínění. Jejich výsledky ukazují, že jde o konstruktově validní nástroj, který je schopen zachytit tendenci k popírání vlastního postoje.

My jsme bohužel nebyli schopni v našich experimentech popření postoje zdokumentovat tak spolehlivě, abychom s ním mohli pracovat v předkládané studii. Na tento jev upozorňujeme proto, aby jej další výzkumníci mohli zahrnout do svých úvah a př́padně mu přizpůsobit uspořádání výzkumu. My jsme s tímto jevem nepočítali, a proto jsme zachytili jen jeho existenci. Nebyli jsme schopni zajistit korektní kódování reakcí během diskusí tváŕí v tváŕ, proto jsme v současné studii pracovali se závisle proměnnou mlčel/mluvil, aniž bychom srovnávali vyjádřené mínění $s$ konzistentně uváděným postojem. $V$ tuto chvíli můžeme nabídnout pouze hypotézy. Domníváme se, že popření vlastního postoje souvisí se strachem z izolace. Svůj postoj by měly popírat především osoby s menšinovým postojem, které vyjadřují vyšší strach $\mathrm{z}$ izolace. Osoby s většinovým postojem jej mohou vyjádřit ve svém mínění věrně bez ohledu na svou míru strachu z izolace. Osoby s nižším strachem z izolace zase postrádají motivaci, proč svůj postoj zapírat. Proto se nám jeví jako nutná predispozice pro zapírání vlastního postoje kombinace vyššího strachu z izolace a menšinového postoje. Tato hypotéza je konzistentní s výsledky Neuwirtha a kol. (2007).

Upozorňujeme, že naše pozorování naznačující zapírání postoje jsme učinili v situaci, kdy účastníci o tématu diskutovali cca 15 minut. Překvapilo nás, že i tak krátký čas k popření vlastního názoru u řady osob stačí. Možná však vycházíme ze špatného normativního předpokladu, že lidé vyjadřují své vnitřní přesvědčení, případně mlčí, avšak $\mathrm{k}$ veřejnému popření jejich mínění je třeba soustavného a dlouhodobého tlaku. Neodpustíme si vyslovit hypotézu, že skutečnost může být přesně opačná. Možná že 15 minutová diskuze v rámci experimentu nestojí participantům za to, aby za své přesvědčení bojovali a prosazovali ho, což je vede k tomu, aby pragmaticky stručně přitakali zcela opačnému stanovisku. Je otázkou, jak by tendence menšiny popírat své přesvědčení vypadala během debat, které by trvaly jednu, dvě nebo dokonce několik hodin. Změnili by členové menšiny pod tlakem své vnitřní postoje na většinové, jak předpokládala Noelle-Neumannová? Nebo by již nedokázali předstírat, že zastávají většinové stanovisko, a začali by hájit své vnitřní přesvědčení, tedy menšinovou názorovou pozici? 
Spirála mlčení není pouhou laboratorní kuriozitou, tento proces má dopad na reálné fungování veřejné sféry. Efekt nadreprezentování většinového názoru a zvýšení jeho utlačivosti již známe z prací Noelle-Neumannové. Spirála mlčení však bude pravděpodobně podporovat růst dnes tak hojně zmiňovaných názorových bublin a s tím spojené názorové polarizace společnosti. Zastánci většinového názoru jsou totiž s menšinovým názorem konfrontováni méně často, než by odpovídalo distribuci názorů, protože část zastánců menšinového názoru v interakci s nimi mlčí. Do názorových bublin se však na základě stejného principu uzavírají i zastánci menšinového názoru. Pokud v nějaké skupině převládnou zastánci názoru, který je na úrovni celé společnosti menšinový, část zastánců opačného názoru bude mít tendenci mlčet, přestože tvoří na úrovni celé společnosti většinu. Mechanismus umlčování názoru, který je menšinový v aktuální diskutující skupině, posiluje navíc ochota vstupovat do diskusí o tématech, kde cítíme podporu pro své názory (Jeffres a kol. 1999; Hayes a kol. 2001).

Právě toto naše výsledky ukazují - jak participanti reagovali, když se během diskusí prímo v laboratoři ocitli v pozici menšiny či většiny. Samozřejmě nemůžeme vyloučit, že ve všech sedmi analyzovaných tématech odpovídalo rozložení názorů celospolečenskému názorovému klimatu, protože jsme toto klima nezjištovali. Otevřenou otázkou pro budoucí výzkum tak zůstává interakce názorového klimatu skupiny a celospolečenského názorového klimatu.

\section{Literatura}

ASCH, Solomon. 1956. „Studies of Independence and Conformity: I. A minority of one against a unanimous group." Psychological Monographs: General and Applied 70(9): 1-70.

BODOR, Tamás. 2012. „The Issue of Timing and Opinion Congruity in Spiral of Silence Research: Why Does Research Suggest Limited Empirical Support for the Theory?" International Journal of Public Opinion Research 24(3): 269-286.

CAMPBELL, Donald T. 1957. „Factors Relevant to the Validity of Experiments in Social Settings.” Psychological Bulletin 54(4): 297-312.

DALISAY, Francis, Jay D. HMIELOWSKI, Matthew James KUSHIN a Masahiro YAMAMOTO. 2012. „Social Capital and the Spiral of Silence.” International Journal of Public Opinion Research 24(3): 325-345.

GLYNN, Carroll J., Andrew F. HAYES a James SHANAHAN. 1997. „Perceived Support for One's Opinions and Willingness to Speak Out: Meta-Analysis of Survey Studies on the Spiral of Silence." The Public Opinion Quarterly 61(3): 452-463.

GLYNN, Carroll J., Susan HERBST, Garrett J. O’KEEFE, Robert Y. SHAPIRO a Mark LINDEMAN. 2004. Public Opinion. Cambridge: Westview Press.

GUNTHER, Albert C., Cindy T. CHRISTEN, Janice L. LIEBHART a Stella Chih-Yun CHIA. 2001. „Congenial Public, Contrary Press, and Biased Estimates of the Climate of Opinion.” The Public Opinion Quarterly 65(3): 295-320.

HAYES, Andrew F., James SHANAHAN a Carroll J. GLYNN. 2001. „Willingness to Express one's Opinion in a Realistic Situation as a Function of Perceived Support for that Opinion.” International Journal of Public Opinion Research 13(1): 45-59.

HAYES, Andrew F., Jörg MATTHES a William P. EVELAND Jr. 2011. „Stimulating the Quasistatistical Organ: Fear of Social Isolation Motivates the Quest for Knowledge of the Opinion Climate." Communication Research 40(4): 439-462. 
HO, Shirley S. a Douglas M. McLEOD. 2008. „Social-Psychological Influences on Opinion Expression in Face- to- Face and Computer-Mediated Communication." Communication Research 35(2): 190-207.

HRBKOVÁ, Lenka a Roman CHYTILEK. 2015. „Př́liš dobré kauzální argumenty na to, aby byly pravdivé? Experimentální validita v postlacourovské době.” Sociální studia 12(4): 7-16.

JEFFRES, Leo W., Kimberly A. NEUENDORF a David ATKIN. 1999. „Spiral of Silence: Expressing Opinions When the Climate of Opinion Is Unambiguous." Political Communication 16(2): 115-131.

KIM, Sei-Hill. 2012. „Testing Fear of Isolation as a Causal Mechanism: Spiral of Silence and Genetically Modified (GM)." International Journal of Public Opinion Research 24(3): 306-324.

KISH, Leslie. 1959. „Some Statistical Problems in Research Design.” American Sociological Review 21(3): 328-338.

KLÍČOVÁ, Kateřina. 2004. „Životní podmínky Romů v České republice v mezinárodním srovnávání v kontextu rizik etnického výzkumu." Pp. 95-115 in Tomáš SIROVÁTKA (ed.). Sociální exkluze a sociální inkluze menšin a marginalizovaných skupin. Brno: Masarykova univerzita + Georgetown.

KOUDELKA, Zdeněk. 2011. Prezident republiky. Praha: Leges s.r.o.

MATTHES, Jörg, Kimberly Rios MORRISON a Christian SCHEMER. 2010. „A Spiral of Silence for Some: Attitude Certainty and the Expression of Political Minority Opinions." Communication Research 20(10): 1-27.

MATTHES, Jörg, Andrew F. HAYES, Hernando ROJAS, Fei SHEN, Seong-Jae MIN a Ivan B. DYLKO. 2012. „Exemplifying a Dispositional Approach to Cross-Cultural Spiral of Silence Research: Fear of Social Isolation and the Inclination to Self-Censor." International Journal of Public Opinion Research 24(3): 287-305.

McDEVITT, Michael, Spiro KIOUSIS a Karin WAHL-JORGENSEN. 2003. „Spiral of Moderation: Opinion Expression in Computer-mediated Discussion.” International Journal of Public Opinion Research 15(4): 454-470.

NEUWIRT, Kurt. 2000. „Testing the spiral of silence model: The case of Mexico.” International Journal of Public Opinion Research 12(2): 138-159.

NEUWIRT, Kurt, Edward FREDERICK a Charles MAYO. 2007. „The Spiral of Silence and Fear of Isolation." Journal of Communication 57(3): 450-468.

NOELLE-NEUMANN, Elisabeth. 1974. „The Spiral of Silence: A Theory of Public Opinion.” Journal of Communication 24(2): 43-51.

NOELLE-NEUMANN, Elisabeth. 1977. „Turbulences in the Climate of Opinion: Methodological Applications of the Spiral of Silence Theory." Public Opinion Quarterly 41(2): 143-158.

NOELLE-NEUMANN, Elizabeth. 1993. The Spiral of Silence: Public Opinion - Our Social Skin. Chicago: The University of Chicago Press.

PETERSEN, Thomas. 2012. „The Enduring Appeal of an Unwieldy Theory.“ International Journal of Public Opinion Research 24(3): 263-268.

SCHEUFELE, A. Dietram a Patricia MOY. 2000. „Twenty-five years of the spiral of silence: a conceptual review and empirical outlook." International Journal of Public Opinion Research 12(1): 3-28.

SCHEUFELE, A. Dietram, James SHANAHAN a Eunjung LEE. 2001. „Real talk: manipulating the dependent variable in spiral of silence research.” Communication Research 28(3): 304-324.

SCHULZ, Anne a Patrick ROESSLER. 2012. „The Spiral of Silence and the Internet: Selection of Online Content and the Perception of the Public Opinion Climate in Computer-Mediated Communication Environments." International Journal of Public Opinion Research 24(3): 346-367.

SOTOLÁ̌̆, Alexandr. 2003. „Legislativa České republiky o omamných a psychotropních látkách se zvláštním zřetelem na trestněprávní aspekty.“Pp. 59-65 in Kamil KALINA a kol. Drogy a drogové závislosti 1: Mezioborový př́stup. Praha: Úřad vlády České republiky.

VAN DIJK, Jan. 2005. The Deepening Divide: Inequality in the Information Society. London: SAGE. 


\section{Autoři}

František Kalvas působí jako odborný asistent na Katedře sociologie Filozofické fakulty Západočeské univerzity v Plzni. Ve své práci se zabývá dynamikou formování veřejného mínění, možnostmi využití multiagentního modelování v sociologii a aplikací laboratorního experimentu v sociálních vědách.

Kontakt:kalvas@kss.zcu.cz

Lucie Přibylová vystudovala magisterský program sociologie na Katedře sociologie Filozofické fakulty Západočeské univerzity v Plzni. Ve své diplomové práci se zabývala teorií spirály mlčení a jejím testováním pomocí laboratorního experimentu.

Kontakt: Pritli@seznam.cz 